American Journal of

Health, Medicine and Nursing Practice (AJHMN)

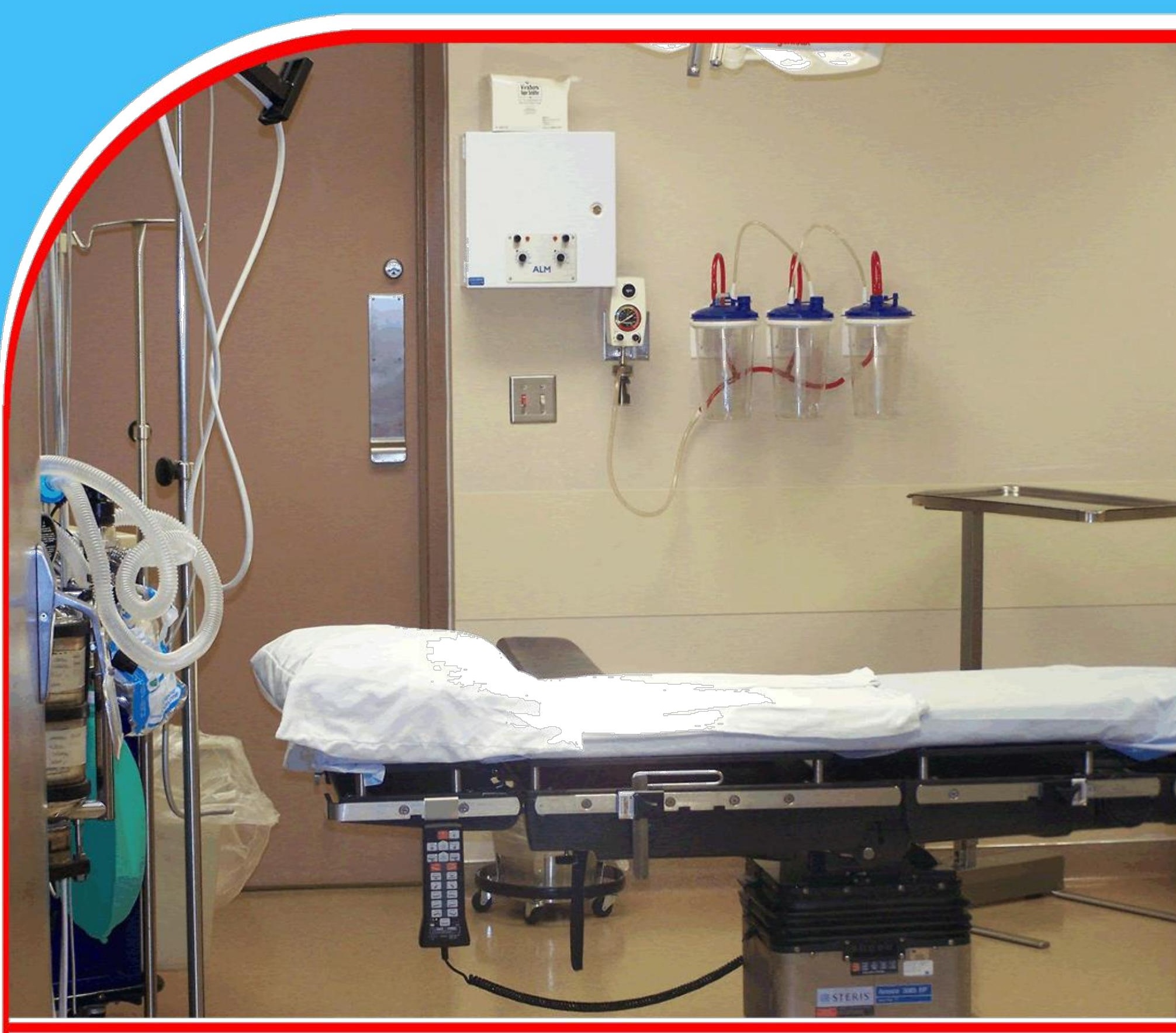

THE EFFECT OF FINANCIAL GOVERNANCE ON FINANCIAL MANAGEMENT SYSTEM EFFECTIVENESS IN HEALTH ORIENTED CIVIL SOCIETY ORGANIZATIONS

Carolyne Wambui, Amos Njuguna 


\title{
THE EFFECT OF FINANCIAL GOVERNANCE ON FINANCIAL MANAGEMENT SYSTEM EFFECTIVENESS IN HEALTH ORIENTED CIVIL SOCIETY ORGANIZATIONS
}

\author{
${ }^{1 *}$ Carolyne Wambui \\ ${ }^{1 *}$ Post Graduate Student \\ United States International University \\ *Corresponding Author's Email: wambui.carol@gmail.com \\ ${ }^{2}$ Amos Njuguna \\ Dean, Chandaria School of Business
}

\begin{abstract}
Purpose: The purpose of this study was to to determine the extent to which financial governance affect financial management system effectiveness in health oriented civil society organizations.

Methodology: The study was conducted through a cross sectional descriptive survey. The target population of the study was 1065 Nongovernmental organizations in Kenya. The accessible population refers to the 606 Nongovernmental organizations located in Nairobi County. A sample of $10 \%$ equivalent to 61 Nongovernmental organizations was selected from the Nongovernmental organizations located in Nairobi County. The respondents were financial managers in every selected Nongovernmental organization. Data was collected by use of a questionnaire and was analyzed by use of inferential and descriptive statistics. Descriptive statistics included frequencies and means. Inferential statistics included correlation, regression and ANOVA analysis. The tool for data analysis was the Statistical Package for Social Sciences (SPSS) version 20. The results were presented using tables and pie charts.
\end{abstract}

Results: Study results indicated that financial governance affects financial management systems effectiveness of NGO's. The results are further supported by a majority of respondents who agreed that the NGO's have a governing body that provides strategic direction and leadership.

Unique contribution to theory, practice and policy: The study recommended that financial governance ought to be thorough throughout the company with sound rules and regulations that governs the accounting and financial sector of the company. This will ensure timely and accurate disclosure of all financial matters regarding the corporation to the regulatory body thus showing the efficiency in financial management systems.

Keywords: financial governance, financial management system, health oriented civil society organization 


\subsection{INTRODUCTION}

\subsection{Background of the Study}

Good financial management is a key to an organizational sustainability as it impacts decision making across the organization and as such should be integrated into all aspects of an organization's operations, from managing project budgets to gathering information for strategic decision-making. Nonprofit voluntary organization must practice sound financial management and comply with a diverse array of legal and regulatory requirements (Liljander and Strandvik, 2010). Whatever the size of the organization, sound financial strategy is a prerequisite to sustainability, rather than being seen as a separate function (merely doing book keeping), the finance should be integrated within, and add value to, the overall planning and management of an organization. It is essential that organizations successfully manage their funding and financing sources to ensure the best and most efficient use of their financial resources (Liljander and Strandvik, 2010).

The financial management processes of not for- profit organizations are generally dominated by conditions of resource scarcity. Such organizations have limited opportunities for generating additional income, but are faced with an ever increasing agenda of programme and activities on which such funds could be spent (Drucker, 2000). Sustainable funding means being able to be there for your beneficiaries in the long term. An organization is financially sustainable if its core work will not collapse if its external funding is withdrawn.

An effective financial management system improves short and long term business performance by streamlining invoicing and bill collection, eliminating accounting errors, minimizing record-keeping redundancy, ensuring compliance with tax and accounting regulations, helping personnel to quantify budget planning, and offering flexibility and expandability to accommodate change and growth (Ogara and Gitoho, 2005). Leaders and managers of NGOs have to develop, at the very least, basic skills in financial management. Basic skills in financial management start in the critical areas of cash management and bookkeeping, which should be carried out following certain financial controls to ensure integrity in the bookkeeping process (Liljander and Strandvik, 2010). New leaders and managers should swiftly learn how to generate financial statements and analyze those statements so as to develop a real understanding of the financial condition of the organization. Financial analysis shows the 'reality' of the situation of an organization and as such, is one of the most important practices in management (Liljander and Strandvik, 2010)

Organizations are required to use funds wisely for the purpose intended and improve the living standards of the populations meant to benefit. Often, uses of funds are diverted to serve other interests of the organization managers outside the scope and work plans of these projects (Liljander and Strandvik, 2010). This has resulted in surprise audits where misuses of funds are suspected by donors and in the extreme cases bank accounts have been frozen to minimize the extent (Ogara and Gitoho, 2005).Good management practices demand that obvious key management concepts and principles such as sustainability, accountability and transparency which are necessary for institutionalized formal procedures are put in place (Ogara and Gitoho, 2005). Most donors attach various restrictions to their funding including among others-sound financial management systems in place, good leadership with integrity, educated staff with and the strategic plans of the organization. NGOs lacking these ingredients have difficulties attracting donor funding (Ogara and Gitoho, 2005). 
Sustainability is the core of organizational effectiveness and connected to all other key components (WCC, 2005). Sustainable strategies must therefore be considered in the areas of strategic direction, moral values, governance, management practices, human resources, and impact of service delivery, financial resources and external relations (WCC, 2005). Sustainable organizations have been found to have at a minimum: A clear mission and strategic direction, the necessary skills to attract resources from a variety of local and international sources, skills and ability to manage resources effectively and efficiently and any effort at organizational regeneration (Ogara and Gitoho, 2005).

A core activity in organizations is the management of financial resources with various accounting cycles of the accounting operation. These cycles initiate financial transaction processing, whose outcomes contribute to the operational, tactical and strategic decisions in organizations. Extended reviews on accounting information systems (AIS) research (Ferguson and Seow, 2011; Poston and Grabski, 2000) provide theories, designs, and categories of AIS research. While there has been coverage of broad topics in AIS research, an important issue of fit of AIS to an organization in a dynamic business environment has not received resolute attention. Past research in information systems has defined system effectiveness in terms of "user information satisfaction" or perceptions of system users about the extent to which the information system available to them meets their information requirements (Nicolaou, 2000).

In general, the NGOs focus on different components needed to achieve their objectives. Health based NGOs provide the communities with the ability, knowledge and confidence to demand the health services they need. The NGOs also partner with national, regional and local health authorities to ensure health benefits to Kenyan citizens. They work together in taking care of infected persons through providing medication and advising on proper nutrition to ensure longevity (Waweru, 2010). NGOs assist those in the health sector to meet its mandate. The mandate of the health sector (hospitals, clinics and dispensaries) is to deliver heath services to its customers taking into consideration the returns to shareholders as well as its role in sustainable development of the community. This mandate is outlined in both the Millennium Development Goals and Vision 2030: to reduce child mortality by two-thirds (MDG 4); reduce maternal mortality by three-quarters (MDG 5); halt and begin to reverse the spread of HIV/AIDS (MDG 6); halt and begin to reverse the incidence of malaria and other major diseases (MDG 6). However, according to Samantha (2011), the penetration of all levels of healthcare service delivery in Kenya is poor which points a finger at both the NGOs and the other or profit institutions operating in the health sector.

\subsection{Problem Statement}

Experience reveals that the financial management processes of NGOs are generally weak and dominated by conditions of resource scarcity vis-à-vis the ever increasing agenda of social development activities on which such funds could be spent (Samantha, 2011). Sustainable funding has helped many NGO's implement diverse programmatic interventions which has not only benefited the communities but has also improved the standard of living. But tough economic times buoyed by global recession have in one way or another affected global funding. Many NGOs continue to cease operations by the day often due to lack of sustainable funding. Many new others are also set-up any day it dawns leaving one with question marks rather than answers as to what's ailing the sector. Many new NGOs fall into the pitfall of unsustainability, as they operate for a summer or for a few years and then fade away (Waweru, 2010). 
The voluntary organization should ensure that annual budgets are approved by the board, its financial system is reliable and all the financial records (accounts) are kept in time. The organizations should assure the financial resources are used in furtherance of the organization's charitable purposes. In order to establish sound governance practices we have to establish an effective structure of overall and financial management. For every voluntary organization and its members it is very much important to understand the basic concept of financial term; budgeting, financial strategy, accounting system, financial policy, social security for its staffs, internal control \& internal audit (Samantha, 2011).

Several studies on financial management systems effectiveness of NGOs have been conducted. These studies include, Magezi (2010), who focused on the relationship between governance and quality of financial reports in NGOs. However, this study did not focus on health NGOs in Kenya. Wamai (2004) conducted a study on the comparative trends in transforming health care systems in Kenya and Finland by focusing on NGO and public health care systems. However, the study failed to address the concept of financial management systems effectiveness of health oriented civil society organizations in Kenya. Kameri-Mbote (2000) conducted a study on the operational environmental and constraints for NGOs in Kenya. However, the study mainly concentrated on the regulatory regime and failed to discuss how NGOs employ financial management systems. Other studies that addressed NGOs are Marete (2007), Mudanya (2007), Odongo (2008), Wairimu (2008), Ombok (2009), Njihia (2009), Keziah (2010), Mutua (2010). Nonetheless, the studies failed to address financial management systems effectiveness of NGOs in the Kenyan health sector. The main research gap stems from the scarcity of studies on this area and the failure of the qualitative factors affecting the financial management systems effectiveness of health oriented civil society organization in Kenya. The study therefore sought to bridge this knowledge gap by assessing the factors affecting the financial management systems effectiveness of health oriented civil society organization in Kenya.

\subsection{Research Objective}

The main objective of the study was to determine the extent to which financial governance affect financial management system effectiveness in health oriented civil society organizations.

\subsection{LITERATURE REVIEW}

\subsection{Empirical Review}

ICGU 2001, states that the Commonwealth Association for Corporate Governance selected leadership as the first principle to enhance corporate governance. NGOs require a governing body to provide strategic direction and leadership. Governing bodies are either called Boards, Trustees, Executive Committees, Management Committees or Councils, (CAFS, 2001). NGOs will need to mature, through increasing professionalization of staff, methods and financing (Cohen, 2003). Harris (1996) states that legally for most NGOs the Board is supposed to govern those NGOs but in practice, the governance may be exercised by a range of stake holders - board, staff, clients, funders, founders and other key stakeholders like government.

Murray, Bradshaw and Wolpin (1992) contend that governance is often shared between headquarters and local branches, which may or may not have their own boards. There has been a push towards decentralization and NGOs have adopted different solutions such as delegation (Fowler 2000, Hope 2002). Eyong (2001) states that good governance means the 
effective management of an NGO's resources in a manner that is open, transparent, accountable, equitable and responsive to people's needs. Good governance aims to ensure management is accountable for the financial and other resources within the boundaries set by the rules of the project. NGOs leadership should establish internal control systems that will ensure a code of ethical conduct and a framework for internal regulations, including systems and bylaws.

Collins and Collins (1978), contend that an accounting system is a way of keeping a written record of transactions. Receipts are given for all money that is received by an organization and receipts are asked for every time money is spent. According to Larson \& Pyle (1988) an accounting system consists of business papers, records, reports and procedures that are used by an organization in recording transactions and reporting their effects. Welsch and Short (1987) said that an accounting system, regardless of the size of the organization is designed to collect, process and report periodic financial information about the entity. According to Keating \& Frumkin (2003), in most NGOs funds from donors are poorly managed and their accounting systems are in poor order. Many NGOs do not have qualified accountants and have problems preparing accurate and timely financial reports, which is one of the major donor requirements.

According to Doornbos (2003) one area that typically comes up for special mention in donorrecipient relationships is that of financial accountability and it stands out as the heart of good governance concerns. Schnelder (1989) stresses that the heart of fiscal management in any organization is a good accounting system, that is appropriate to that organization. In order to achieve consistent financial accountability it is necessary to establish standards and a system for accounting practices. Ebrahim (2003) notes that NGOs respond to issues of accountability with both tools and processes. Tools are created by stakeholders that have considerable leverage over an NGO like a donor or a government regulator. Familiar tools are annual reports, financial accounts, performance assessments, quarterly reports, independent evaluations and audits. Keating and Frumkin (2003) state that in order to determine the effectiveness of a financial reporting system, one must understand its objectives. Policy makers design systems that meet the basic criteria of quality information, which are reliability and relevance.

Poor leadership, which presented a challenge, as alluded to by Kraak (2001) in his study governance and financial sustainability of NGOs in South Africa, can be ascribed to the advent of a democratic and legitimate state which freed those who were unwilling to be associated with the apartheid state, to now work for the new state. NGO, CBO and trade union human resource capacity became depleted. A new generation of leadership struggled to build its expertise.

According to the Institute of Corporate Governance of Uganda (ICGU) (2001), corporate governance should put in place a framework to ensure timely and accurate disclosure of all material matters regarding the corporation, including the financial situation, performance, ownership and the governance of the company. According to the Asian Development Bank (ADB) (2005), transparency and information openness cannot be assured without the legal frameworks that balance the right to disclose against the right of confidentiality. Similarly, predictability in the functioning of the legal framework is helpful for ensuring the accountability of institutions. A transparent system facilitates accountability, participation and predictability of outcomes (Institute of Corporate Governance of Uganda (ICGU), 2001) .Transparency means that decisions taken and their enforcement are done in a manner that 
follows rules and regulations. It also means that information is freely available and directly accessible to those who will be affected by such decisions and their enforcement (Institute of Corporate Governance of Uganda (ICGU), 2001). It also means that enough information is provided and that it is provided in easily understandable forms and media.

According to Tilt (2006) the most important issue when considering accountability of NGOs is the means by which they will be required to provide an account. Marshall (2002) also adds that the most obvious way to ensure that NGOs are transparent is a full disclosure about their activities, which will enhance public trust. However, according to Marshall (2002) in addition to this explanatory accountability there also needs to be accountability with sanctions, where some form of penalty is imposed if the account or the actions are inadequate.

\subsection{RESEARCH METHODOLOGY}

The study was conducted through a cross sectional descriptive survey. The target population of the study was NGOs working in the health sector in Kenya. The study focused on 1065 NGOs. From the 1065 NGOs, 606 NGOs are located in Nairobi. This formed the accessible population. The unit of analysis was the financial manager of each NGO as he/she was more conversant with the information that was being sought. The sampling frame was retrieved from the NGO Coordination Board website and this was up to date by 30 December, 2012. Simple random sampling was used. The NGOs were listed on a piece of paper and the papers were folded and 61 papers picked without replacement. However, the $10 \%$ would yield 61 NGOs, a figure that was not too large or too small considering the logistics and the economic resources at the disposal of the researcher. The study used a questionnaire as the preferred data collection tool. The study used the quantitative method of data analysis. Quantitative methods of data analysis include inferential and descriptive statistics. The rationale for using quantitative methods for data analysis was because some of the data results required quantitative interpretation. Inferential statistics included regression modeling, and correlation analysis. The tool for data analysis was Statistical Package for Social Sciences (SPSS) version 20 program. The results were presented using tables and pie charts to give a clear picture of the research findings.

\subsection{RESULTS AND DISCUSSIONS}

\subsection{Response Rate}

All questionnaires (61) that were distributed were received for data analysis.

\subsection{Demographic Characteristics}

\subsubsection{Gender of Respondents}

The study sought to establish the gender of respondents of NGOs operation. Gender of respondents is important since it may influence financial management system effectiveness. The respondents were requested to indicate their gender. $(54.1 \%)$ of the respondents were male while the rest, $45.9 \%$ were female. The results indicate that the finance department was a male dominant field. The results are in Figure 1. 


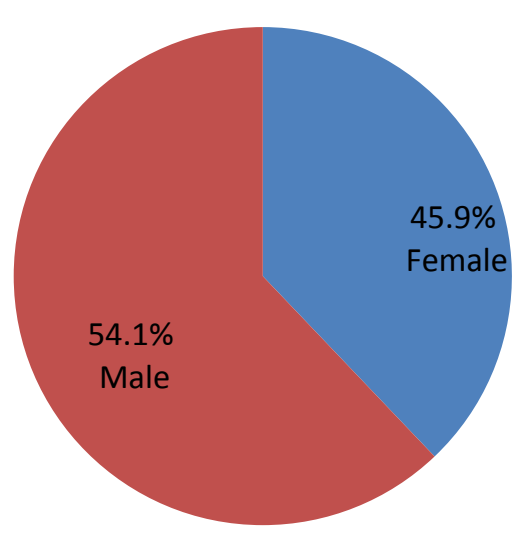

Figure 1: Gender of Respondents

\subsubsection{Level of Education}

The study sought to establish the level of education of respondents of NGOs operation. Level of education is important since it may influence financial management system effectiveness. The respondents were requested to indicate their level of education. Results indicate that (49.2\%) of the respondents indicated that their highest level of academic qualification was university level. (21.3\%) indicated that their highest level of academic achievement was college while a further $(29.5 \%)$ were post graduate. The findings implied that the employees in NGOs are highly qualified and this may have a positive implication on the level of financial management system effectiveness. These results are shown in Table 1.

Table 1: Level of Education

\begin{tabular}{|l|c|c|}
\hline Education Level & Frequency & Percent \\
\hline College & 13 & 21.3 \\
\hline University & 30 & 49.2 \\
\hline Postgraduate & 18 & 29.5 \\
\hline Total & 61 & 100 \\
\hline
\end{tabular}

\subsubsection{Period Employed}

The study sought to establish the period employed in NGOs operation. Period of employment is important since it may influence financial management system effectiveness. The respondents were asked to indicate their period of employment. (41\%) of the respondents indicated that they had been working between 2 to 5 years. A further $(31 \%)$ has been working in the NGOs for 6 to 10 years, $(10 \%)$ for 11 to 15 years while $(22 \%)$ have been working in the NGOs for 10 and above years and $(21.3 \%)$ have been working for over 10 years while (6.6\%) had been employed in the NGOs sector for less than one year. The findings imply that the employee set consists of employees of varying experience. The results are in Figure 2. 


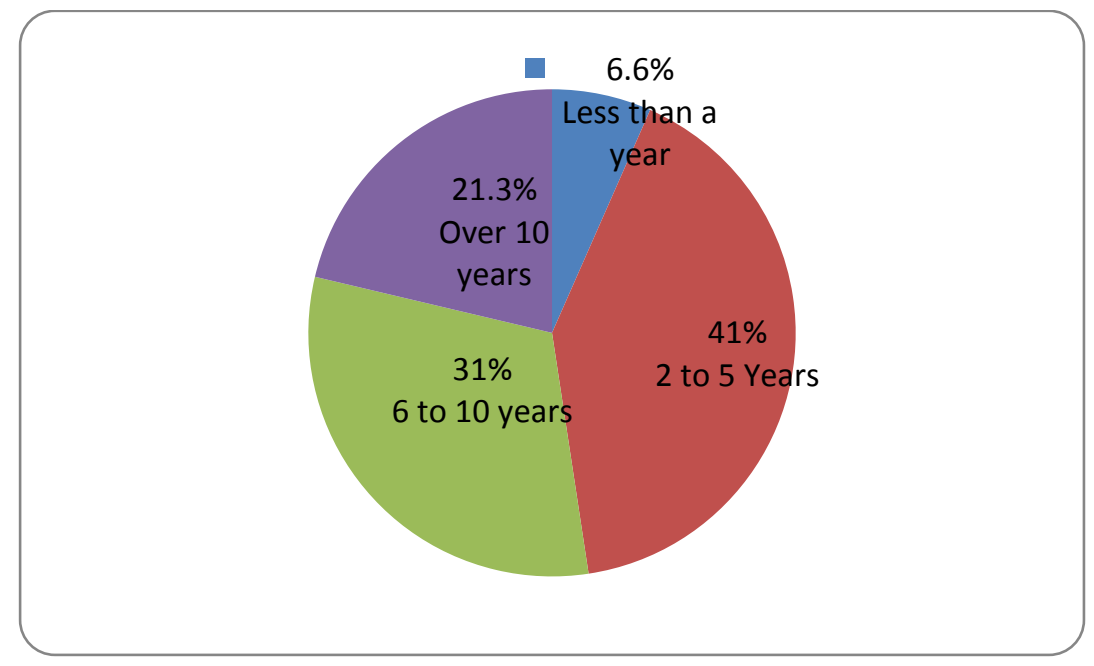

\section{Figure 2: Period Employed}

\subsubsection{NGO Years of Operation}

The study sought to establish the NGOs years of operation. NGOs years of operation are important since it may influence financial management system effectiveness. The results on the years of operation of the NGO are presented in Table 2. The majority of the respondents indicated that majority of the registered NGO's in Kenya have been operating for over 10 years and between 6 to 10 years as represented by $(42.6 \%)$ and $(36.1 \%)$ respectively. Few NGO's have operations between 2 to 5 years as indicated by a percent of (19.7\%). The results are shown in Table 4.2.The findings implied that majority of the NGOs had been in operation for a long time therefore the findings were reliable.

Table 2: Age of NGO

\begin{tabular}{|l|c|c|}
\hline Period of NGO Operation & Frequency & Percent \\
\hline Less than 1 year & 1 & 1.6 \\
\hline 2 to5 years & 12 & 19.7 \\
\hline 6 to 10 years & 22 & 36.1 \\
\hline Over 10 years & 26 & 42.6 \\
\hline Total & $\mathbf{6 1}$ & $\mathbf{1 0 0}$ \\
\hline
\end{tabular}

\subsubsection{Scope of NGO's Operation}

The study sought to establish the scope of NGOs operation. Scope of NGOs operation is important since it may influence financial management system effectiveness. Results in Figure 3 shows that majority of the NGO's in Kenya have operations locally as indicated by (54\%), while those operating at a regional extent are at (38\%). Eight percent (8\%) represent the NGO's whose operation is at an international level. This implied that there are many running NGOs locally based to help the poor communities. 


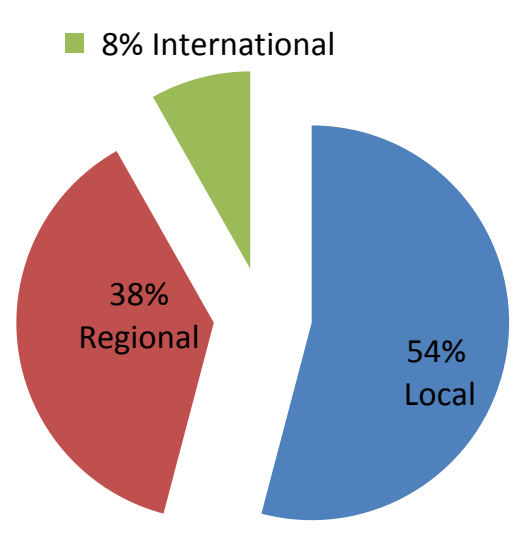

\section{Figure 3: Scope of NGO}

\subsubsection{NGOs' Sources of Funding}

The study sought to establish the NGOs' sources of funding. NGOs' sources of funding are important since it may influence financial management system effectiveness. Sources of funding for the majority of the NGO's in Kenya is through donors as represented by $(87 \%)$ while $(13 \%)$ shows that some of the funding from some NGO's is received from the local community. The results of this finding are represented in Figure 4.The findings imply that most running NGOs are supported by the donor to accomplish their mission.

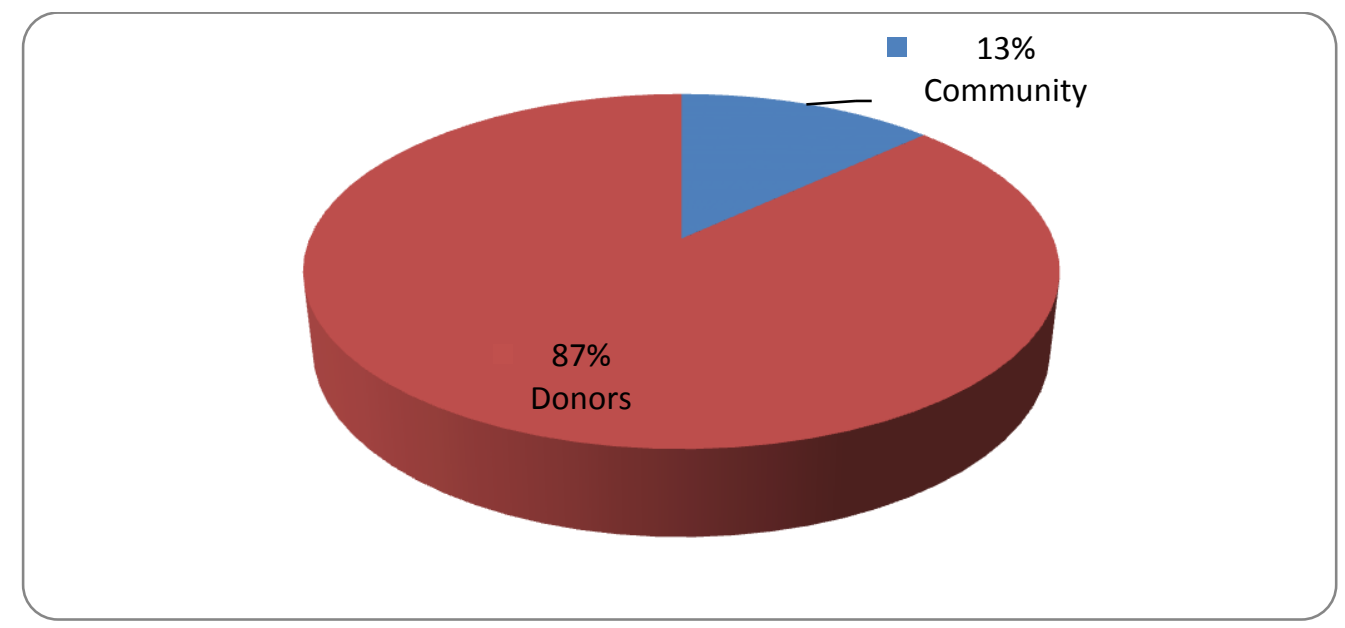

\section{Figure 4: Sources of funds}

\subsection{Descriptive Statistics}

\subsubsection{Presence of a Governing Body That Provides Strategic Direction and Leadership}

The respondents were asked whether the organization had a governing body to provide strategic direction and leadership. Presence of a governing body that provides strategic direction and leadership of the organization financial management may influence financial management system effectiveness. Majority at (65.6\%) agreed while another at $(13.10 \%)$ strongly agreed bringing to a total of $(78.7 \%)$ of those who agreed. Further, $(14.80 \%)$ neither agreed nor disagreed while $(4.90 \%)$ disagreed and (1.60\%) strongly disagreed. The results are presented in Table 3. 
Table 3: Presence of a Governing Body That Provides Strategic Direction and Leadership

\begin{tabular}{|c|c|c|c|}
\hline Statement & Scale & Frequency & Percentage \\
\hline \multirow{5}{*}{$\begin{array}{l}\text { The organization has a governing body to } \\
\text { provide strategic direction and leadership }\end{array}$} & Strongly Disagree & 1 & $1.60 \%$ \\
\hline & Disagree & 3 & $4.90 \%$ \\
\hline & Neutral & 9 & $14.80 \%$ \\
\hline & Agree & 40 & $65.60 \%$ \\
\hline & Strongly agree & 8 & $13.10 \%$ \\
\hline
\end{tabular}

4.3.2 Good Governance to Ensure Accountability in Financial and Other Resources

The respondents were asked whether the organization has set good governance to ensure management is accountable for the financial and other resources within the boundaries set by the rules of the project. Good governance of the organization financial management may influence financial management system effectiveness. (44.3\%) agreed while another and $(19.7 \%)$ strongly agreed bringing to a total of $(64 \%)$ of those who agreed with the statement. Further, $(26.2 \%)$ neither agreed nor disagreed while (4.9\%) disagreed and (4.9\%) strongly disagreed. The results are presented in Table 4.

Table 4: Good Governance to Ensure Accountability in Financial and Other Resources

\begin{tabular}{|l|l|r|r|}
\hline Statement & Scale & Frequency & Percentage \\
\hline $\begin{array}{l}\text { The organization has set good governance to } \\
\text { ensure management is accountable for the } \\
\text { financial and other resources within the } \\
\text { boundaries set by the rules of the project }\end{array}$ & & & \\
& $\begin{array}{l}\text { Strongly } \\
\text { Disagree }\end{array}$ & 3 & $4.90 \%$ \\
\cline { 2 - 4 } & Disagree & 3 & $4.90 \%$ \\
\cline { 2 - 4 } & Neutral & 16 & $26.20 \%$ \\
\cline { 2 - 5 } & Agree & 27 & $44.30 \%$ \\
\cline { 2 - 5 } & Strongly agree & 12 & $19.70 \%$ \\
\hline
\end{tabular}

4.3.3 Well Management of Organization and Accounting Systems

The respondents were asked whether the organization is well managed and their accounting systems are in good order. Organization management and accounting systems may influence financial management system effectiveness. The responses received indicated (41\%) agreed while another $(26.2 \%)$ strongly agreed bringing to a total of $(67.2 \%)$ of those who agreed. Further $(26.2 \%)$ neither agreed nor disagreed, while $(3.3 \%)$ disagreed and $(3.3 \%)$ strongly disagreed.

Table 5: Well Management of Organization and Accounting Systems

\begin{tabular}{|l|c|c|c|}
\hline Statement & Scale & Frequency & Percentage \\
\hline The organization is well managed and their & Strongly & 2 & $3.30 \%$ \\
accounting systems are in good order & Disagree & 2 & $3.30 \%$ \\
\cline { 2 - 4 } & Disagree & 16 & $26.20 \%$ \\
\cline { 2 - 4 } & Neutral & 25 & $41.00 \%$ \\
\cline { 2 - 4 } & Agree & 16 & $26.20 \%$ \\
\cline { 2 - 4 } & Strongly agree & & \\
\end{tabular}




\subsubsection{Proper Framework to Ensure Timely and Accurate Disclosure of Material Matters}

The respondents were asked whether the organization has put in place a framework to ensure timely and accurate disclosure of all material matters regarding the corporation. Proper framework of the organization financial management may influence financial management system effectiveness. Majority of the respondents at (75.4\%) agreed while another and (4.90\%) strongly agreed bringing to a total of $(80.3 \%)$ of those who agreed. Further, $(13.1 \%)$ were neutral while $(4.90 \%)$ disagreed and $(1.60 \%)$ strongly disagreed.

Table 6: Proper Framework to Ensure Timely and Accurate Disclosure of Material Matters

\begin{tabular}{|l|c|c|c|}
\hline Statement & Scale & Frequency & Percentage \\
\hline $\begin{array}{l}\text { The organization has put in place a } \\
\text { framework to ensure timely and accurate } \\
\text { disclosure of all material matters regarding } \\
\text { the corporation }\end{array}$ & Strongly Disagree & 1 & $1.60 \%$ \\
\cline { 2 - 4 } & Disagree & 3 & $4.90 \%$ \\
\cline { 2 - 4 } & Neutral & 8 & $13.10 \%$ \\
\cline { 2 - 4 } & Agree & 46 & $75.40 \%$ \\
\cline { 2 - 4 } & Strongly agree & 3 & $4.90 \%$ \\
\hline
\end{tabular}

4.3.5 Presence of Qualified Accountants for Accurate and Timely Preparation of Financial Reports

The respondents were asked whether the organization has qualified accountants and has no problems preparing accurate and timely financial reports. Qualified accountants of the organization financial management may influence financial management system effectiveness. A majority at (47.5\%) agreed while another at (8.2\%) strongly agreed bringing to a total of $(55.7 \%)$ of those who agreed. Further, $(26.2 \%)$ neither agreed nor disagreed while $(14.8 \%)$ disagreed and $(3.30 \%)$ strongly disagreed. The results are presented in Table 7.

Table 7: Presence of Qualified Accountants for Accurate and Timely Preparation of Financial Reports

\begin{tabular}{|l|c|c|c|}
\hline Statement & Scale & Frequency & Percentage \\
\hline $\begin{array}{l}\text { The organization has qualified accountants } \\
\text { and has no problems preparing accurate } \\
\text { and timely financial reports }\end{array}$ & Strongly Disagree & 2 & $3.30 \%$ \\
\cline { 2 - 4 } & Disagree & 9 & $14.80 \%$ \\
\cline { 2 - 4 } & Neutral & 16 & $26.20 \%$ \\
\cline { 2 - 4 } & Agree & 29 & $47.50 \%$ \\
\cline { 2 - 4 } & Strongly agree & 5 & $8.20 \%$ \\
\hline
\end{tabular}

Results reveal that majority of NGOs had put in place financial governance measures. This included the presence of a governing body that provides strategic direction and leadership, the existence of good governance to ensure accountability in financial and other resources, good management of organization and accounting systems, proper framework to ensure timely and accurate disclosure of material matters, presence of qualified accountants for accurate and timely preparation of financial reports. 


\subsection{DISCUSSION CONCLUSIONS AND RECOMMENDATIONS}

\subsection{Discussion}

Study results indicated that financial governance affects financial management systems effectiveness of NGO's. The results are further supported by a majority of respondents who agreed that the NGO's have a governing body that provides strategic direction and leadership. The findings agree with those of Eyong (2001) who states that good governance means the effective management of an NGO's resources in a manner that is open, transparent, accountable, equitable and responsive to people's needs. Good governance aims to ensure management is accountable for the financial and other resources within the boundaries set by the rules of the project. NGO leadership should establish internal control systems that will ensure a code of ethical conduct and a framework for internal regulations, including systems and by laws.

Study findings also indicated that the majority agreed with the statement that NGO have set good governance to ensure management is accountable for the financial and other resources within the boundaries set by the rules of the project. The findings support those of Eyong (2001) who states that good governance means the effective management of an NGO's resources in a manner that is open, transparent, accountable, equitable and responsive to people's needs. Good governance aims to ensure management is accountable for the financial and other resources within the boundaries set by the rules of the project. Further the findings confer with those of Cohen, Krisnamoorthy and Wright (2004) who state that one of the most important functions of corporate governance is to ensure the quality of financial reports. According to Sioan (2001) the financial report is the first source of independent and true communication about performance of company managers

Study results indicated that majority of the respondents agreed with the statements that the organization is well managed and their accounting systems are in good order. The findings agree with those of Tilt (2006) who asserted that the most important issue when considering accountability of NGO is the means by which they will be required to provide an account. Marshall (2002) also adds that the most obvious way to ensure that NGO are transparent is a full disclosure about their activities, which will enhance public trust. However, according to Marshall (2002) in explaining accountability there also needs to be accountability with sanctions, where some form of penalty is imposed if the account or the actions are inadequate.

Study results indicate that most NGO have put in place a framework to ensure timely and accurate disclosure of all material matters regarding the corporation. These findings agree with those of Institute of Corporate Governance of Uganda (ICGU) (2001) which noted that corporate governance should put in place a framework to ensure timely and accurate disclosure of all material matters regarding the corporation, including the financial situation, performance, ownership and the governance of the company. According to the Asian Development Bank (ADB) (2005), transparency and information openness cannot be assured without the legal frameworks that balance the right to disclose against the right of confidentiality. Similarly, predictability in the functioning of the legal framework is helpful for ensuring the accountability of institutions. A transparent system facilitates accountability, participation and predictability of outcomes (Institute of Corporate Governance of Uganda (ICGU), 2001). Transparency means that decisions taken and their enforcement are done in a manner that follows rules and regulations. It also means that information is freely available and directly accessible to those who will be affected by such decisions and their enforcement. 
It also means that enough information is provided and that it is provided in easily understandable forms and media.

Study results indicate that the organization has qualified accountants and has no problems preparing accurate and timely financial reports. Ebrahim (2003) notes that NGOs respond to issues of accountability with both tools and processes. Tools are created by stakeholders that have considerable leverage over an NGO like a donor or a government regulator. Familiar tools are annual reports, financial accounts, performance assessments, quarterly reports, independent evaluations and audits. Keating and Frumkin (2003) state that in order to determine the effectiveness of a financial reporting system, one must understand its objectives. Policy makers design systems that meet the basic criteria of quality information, which are reliability and relevance.

\subsection{Conclusions}

The findings led to conclusions that the NGOs have the good governance to ensure accountability in financial and other resources. The findings led to conclusions that the NGOs have good management of organization and accounting systems. The findings led to conclusions that the NGOs have proper framework to ensure timely and accurate disclosure of material matters. The study also led to conclusion that the NGOs have presence of qualified accountants for accurate and timely preparation of financial reports. The study results also led to conclusions that assisted financial management of staff has led to efficient management of processes of budget accounting. The Regression results led to the conclusion that the relationship between financial governance and financial management system was positive and significant.

The study led to conclusion that organizations with good corporate governance have the capacity to maintain high-quality services and to deliver improvement. Poor governance arrangements set the framework within which the organizational systems and processes fail to detect or anticipate serious service and financial failures.

Study result also led to conclusion that an organization should ensure that board advises management in the development of strategic priorities and plans that align with the mission of the organization and the best interests of stakeholders, and that have an appropriate short, mid and long range focus. The board also actively monitors management's execution of approved strategic plans as well as the transparency and adequacy of internal and external communication of strategic plans.

\subsection{Recommendations}

The study recommended that financial governance ought to be thorough throughout the company with sound rules and regulations that governs the accounting and financial sector of the company. This will ensure timely and accurate disclosure of all financial matters regarding the corporation to the regulatory body thus showing the efficiency in financial management systems.

\subsection{Areas for Further Studies}

A replica study could be done on a governmental institution and the survey results would be used for comparative analysis between nongovernmental institutions and governmental, (public) institutions. Further studies could also include other factors such availability of resources, leadership or culture of the organization and the rules and regulations of the financial governing bodies or local authorities that affects the effectiveness of financial management systems in companies. 


\section{REFERENCES}

Cohen. J. (2003). Governance by and of NGOs, Institute of Social and Ethical Accountability, UK.

Ebrahim, Alnoor, (2003). Accountability in Practice: Mechanisms for Donor NGOs, World Development, Vo. 1394.

Eyong T. O. (2001). Promoting Good Governance in the Management of NGOs.

Ferguson, C., and Seow,P. S. (2011). Accounting information systems research over the past decade: Past and future trends, Accounting \& Finance, 51, 235-251.

Fowler. A. (2000). Relevance in the Twenty-first Century: The Case for Devolution and Global Association of International NGOs" in D. Eade (Ed).

Harris M. (1996). Do we need Governing Bodies? in D. Billis and M. Harris (Eds) Voluntary Agencies: Challenges of Organization and Management.

Hope K. (2002).The New Public Management: A Perspective from Africa, in K. McLaughin, S. Osborne and E. Feline (Eds), New Public Management: Current trends and Future Prospects: London: Routledge

Kameri-Mbote, P. (2000). The Operational Environment and Constraints for NGOs in Kenya: Strategies for Good Policy and Development. Switzerland: International Environmental House.

Keating, Elizabeth \& Frumkin. (2003). Assessing Non Profit Making Financial Measures, Accountability and Evaluation, Non-Profit Sector Research Fund.

Keziah, M. (2010). The Strategic Responses Adopted by KPA to Changing External Environment. University of Nairobi: Unpublished MBA Project.

Mareta, N.C. (2007). The Strategic Response of Glaxosmithkline Pharmaceuticals towards competition in Kenya.Unpublished MBA Thesis. University of Nairobi

Marshall M. (2002). Legitimacy and Effectiveness: Civil Society Organizations' Role in Good Governance, Paper presented at the Poverty Reduction Strategies Forum, Austria, October 29 - November 1, 2002.

Mudanya, S. M. (2007). Response Strategies to Environmental Challenges to firms in the Cement Industry in Kenya. University of Nairobi: Unpublished MBA Project.

Murray, Bradshaw and Wolpin. (1992). Do Nonprofits Boards make a difference? An exploration of the relationships among the board structure, process and effectiveness, Nonprofit and Voluntary Sector Quarterly.

Mutua, C.K. (2010). Strategic Responses by the Deposit Protection Fund Board to Changes in the External Environment. University of Nairobi: Unpublished MBA Project.

NGOs, in Bendell, J. (Eds),Terms for Endearment, Greenleaf Publishing, Sheffield.

Njihia, N.N. (2009). Strategic Responses of Kenya Commercial Bank Limited to Changes in Kenyan Banking Industry. University of Nairobi: Unpublished MBA Project.

Odongo, T.O. (2008). Strategic Responses by Kenya Tourist Development Corporation to Changes in its Environment. University of Nairobi: Unpublished MBA Project.

Ogara, W. (2005). Church Financial Sustainability. Catholic University of Eastern Africa 
Ombok, F.S.A. (2009). Response Strategies of International Non-governmental Organizations in Nairobi to Changes in the Macro Environment. University of Nairobi: Unpublished MBA Project

Poston, R. and Grabski,S. (2000).Accounting information systems research: Is it another qwerty. International Journal of Accounting Information Systems, 1, 9-53.

Rafferty, A. E., \& Griffin, M. A. (2004). Dimensions of transformational leadership: Conceptual and empirical extensions. The Leadership Quarterly, 15, 329-354.

Romney, M. B., and Steinbart P. J. (2011). Accounting infromation systems. (Pearson).

Schnelder, W. A. (1989). Financial Management in Church Organizations. The CPA Journal online April 1989, Accessed on 25 January 2004 at www.nysscpa.org/cpajournal/old/07299394.html

Tilt. (2006). Considering NGO Accountability: A Note of Caution, Eighth Biennial Conference, School of Commerce, Flinders University.

Turban, E,.and VoloninoL. (2011). Information technology for management. (Wiley).

Wamai, G.R. (2004). NGO and Public Health Systems: Comparative Trends in Transforming Health Care Systems in Kenya and Finland. Researcher. University of Helsinki, Finland. Department of Social Policy/Institute of Development Studies. 